\title{
The health of the Roma people: a review of the published literature
}

\author{
Steve Hajioff, Martin McKee
}

\begin{abstract}
Background-The Roma people originated in northern India and have been known in Europe for nearly a thousand years. For much of that time they have been the subjects of discrimination and oppression, culminating in the extermination of half a million Roma in the Nazi death camps. While it is widely believed that the health of Roma people is often poorer than the majority population, these inequalities remain largely unresearched.

Methods-Published literature on the health of the Roma people was identified using Medline. Opinion pieces were excluded, as were papers relating to anthropometry and to genetic markers. The resultant papers were analysed by country of study and by disease type or care group. Results-Some $70 \%$ of papers identified related to just three countries; Spain and the Czech and Slovak Republics. Much literature concentrates upon communicable disease or reproductive health. The limited evidence suggests increased morbidity from non-communicable disease, but there is little published on this topic. Evidence on health care, though fragmentary, suggests poorer access to health services and uptake of preventative care.

Discussion-Published research on the health needs of the Roma population is sparse. The topics that have received attention suggest a focus on concepts of contagion or social Darwinism, indicating a greater concern with the health needs of the majority populations with which they live. There is a need for both further research into the health of Roma people; with particular emphasis on noncommunicable disease; and also for interventions that improve Roma health. Such research must, however, be handled with sensitivity, recognising the social and political context of the society concerned. (F Epidemiol Community Health 2000;54:864-869)
\end{abstract}

European Centre on Health of Societies in Transition, London School of Hygiene and Tropical Medicine, Keppel Street, London WC1E 7HT

Correspondence to: Dr Hajioff

(steve.hajioff@1shtm.ac.uk)

Accepted for publication 8 May 2000 were on a pilgrimage from Egypt in penitence for once forsaking Christianity. ${ }^{2}$

Although initially welcomed, their subsequent reception varied. In 14th century Ragusa (Dubrovnik) they were free citizens (albeit low on the social scale), while in Kosovo, Moldavia and Wallachia they were enslaved. The emergence of the nation state in the 16th century brought widespread intolerance. ${ }^{6}$ France and England barred them entry and Sweden, Denmark and Portugal expelled them. Throughout the 17 th century, punitive policies were widely adopted, such as restrictions upon trade and shelter, prohibition of traditional dress or the speaking of Romani, and restrictions on Roma gatherings. Penalties included death and corporal punishment.

In the 18th century punishments continued on the basis of ethnicity. In Austro-Hungary, Roma children were taken from their parents and brought up by other families, a practice that continued in some countries until the 20th century. ${ }^{7}$

The 19th century saw an improvement in their treatment in most of Europe, with abolition of slavery and granting of legal rights. The latter part of the 19th and the early 20th centuries, however, were characterised by the theories of eugenics that contributed to the extermination of half a million Roma in Nazi camps. $^{8}$

Conditions improved in much of Europe in the postwar period although some countries encouraged or compelled Roma families to settle and segregated education denied learning opportunities. The collapse of communism had major implications for the Roma population, with an upsurge in racist attacks, often with semi-official sanction, in states experiencing re-emergent nationalism.

Roma health is thought to lag behind that of majority populations, with some studies suggesting a fourfold increase in infant mortality and a 10 year deficit in life expectancy ${ }^{9}$ but research on the health of the Roma is limited and difficult to access. ${ }^{6}$ This paper seeks to advance this issue by examining in detail published research on the health of the Roma population that is accessible to the international community.

This presents challenges. The paucity of literature limits the scope for international comparison, and the small number of active researchers means that, for many countries, no information is accessible. Differences in terminology are problematic; the term traveller, used in the United Kingdom, is unfamiliar in countries where the Roma population is largely 
settled. "Traveller" also includes non-Roma people who have itinerant lifestyles.

It is, however, important not to fall into the trap of equating absence of evidence on Roma health with evidence of absence of health inequalities.

\section{Methods}

Publications were identified by a search of Medline (1966 to 1999) (Silver Platter). An initial search, using the keyword "Roma" yielded mainly references unrelated to the Roma people, but rather, the capital city of Italy. Alternative keywords used were: gypsy, gipsy, gypsies, gipsies, romany, vlach, traveller. Of the 693 citations identified, 378 were tagged "human". Individual case reports, news reports and articles tagged "comment" were excluded. Examination of the remainder showed a proportion relating to genetic detection of Roma ancestry, or to arthropods (with the gypsy moth and gypsy variant of the Drosophila fruit fly commonly cited). Papers including "moth" or "genetics" as keywords were therefore excluded. After these exclusions, through multiple Boolean searches, a total of 175 papers remained (of which 65 were in English and 110 in other languages). The abstracts were manually assessed by the researchers for relevance to the Roma people, rather than other nomadic non-Roma groups, and health or healthcare. One hundred and five citations remained and the original papers were obtained and summarised, where necessary, into English. A search of the HealthSTAR database yielded six citations. A further Medline search was performed using the Ovid system, focusing solely on the thesaurus term "gypsies". The findings of the two searches are compared in table 1 . The 62 citations from the

Table 1 Number of citations identified in Medline searches

\begin{tabular}{lll}
\hline Phase & $\begin{array}{l}\text { Detailed } \\
\text { search }\end{array}$ & $\begin{array}{l}\text { Thesaurus term } \\
\text { only search }\end{array}$ \\
\hline Initial search & 693 & 229 \\
After Boolean exclusions & 175 & 187 \\
After direct reviewer scrutiny and exclusion & 105 & 62 \\
\hline
\end{tabular}

Table 2 Estimates of Roma population in various European countries, early 1990 s

\begin{tabular}{|c|c|c|c|}
\hline \multirow[b]{2}{*}{ Country } & \multicolumn{2}{|c|}{ Roma population (thousands) } & \multirow[b]{2}{*}{$\begin{array}{l}\text { Total population } \\
\text { (millions) }\end{array}$} \\
\hline & $\begin{array}{l}\text { Official } \\
\text { statistics }\end{array}$ & $M R G^{\star}$ estimates & \\
\hline Albania & & $90-100$ & 3.2 \\
\hline Austria & & $20-50$ & 7.9 \\
\hline Bosnia-Herzegovina & & $40-50$ & 4.0 \\
\hline Bulgaria & 577 & $700-800$ & 8.9 \\
\hline Croatia & & $400-450$ & 4.6 \\
\hline Czech Republic & 146 & $250-300$ & 10.4 \\
\hline France & & $280-340$ & 57.9 \\
\hline Germany & & $110-130$ & 81.5 \\
\hline Greece & & $160-200$ & 10.5 \\
\hline Hungary & 400 & $550-600$ & 10.3 \\
\hline Italy & & $90-110$ & 57.9 \\
\hline Poland & 30 & $50-60$ & 38.5 \\
\hline Romania & 430 & $1800-2500$ & 2.3 \\
\hline Russia & 262 & $220-400$ & 147 \\
\hline Slovakia & 254 & $480-520$ & 5.3 \\
\hline Spain & & $650-800$ & 39.2 \\
\hline Turkey & & $300-500$ & 63.8 \\
\hline Ukraine & & $50-60$ & 51.2 \\
\hline United Kingdom & & $90-120$ & 58.4 \\
\hline Yugoslavia & & $400-450$ & 10.6 \\
\hline
\end{tabular}

^Minority Rights Group.
Table 3 Number of publications identified by country

\begin{tabular}{ll}
\hline Country & $\begin{array}{l}\text { Number of } \\
\text { papers identified }\end{array}$ \\
\hline Spain & 24 \\
Czech Republic & 19 \\
Slovakia & 16 \\
Hungary & 14 \\
United States of America & 8 \\
United Kingdom & 6 \\
Germany & 5 \\
Bulgaria & 5 \\
Other & 13 \\
\hline
\end{tabular}

second search were a subset of the 105 from the first. A search of the world wide web using the HotBot search engine yielded many hits but these were of limited usefulness.

\section{Results}

An initial question is the size of the Roma population. Estimates from different sources can vary ${ }^{10}$ for several reasons. The history of oppression and forced assimilation in some countries may make people loath to declare Roma ethnicity. Some countries have only recently recognised the Roma as an ethnic group for the purposes of census and others still do not. Roma people are often socioeconomically deprived. This, added to itinerant lifestyle and a mistrust of authority figures may contribute to under-ascertainment. Taking these issues into account, the Minority Rights Group ${ }^{11}$ compiled estimates of the populations in various European countries in the early 1990s (table 2). These do not include recent mass movements of population in the former Yugoslavia.

Turning to the literature on health among the Roma, there is considerable variation in the number of citations from each country, which bears little relation to population size.

Table 3 shows the distribution of papers by the country in which they are set. Some publications relate to more than one country so are counted for each country concerned.

Seventy per cent of publications relate to just four countries: Spain (24 papers), Czech Republic (19 papers), Slovakia (16 papers) and Hungary (14 papers). Nations classed as "other" included Sweden, Romania, France and Italy, each of which contributed two papers, with single papers from each of: Slovenia, Greece, Russia, Mexico and Jordan.

Table 4 shows papers grouped by care group, disease or subject. Some covered more than one category: "children" and "communicable

Table 4 Number of papers by subject matter

\begin{tabular}{lc}
\hline Subject matter & $\begin{array}{c}\text { Number } \\
\text { of papers }\end{array}$ \\
\hline Child health & 34 \\
Older people & 2 \\
Communicable disease & 32 \\
Non-communicable disease & 5 \\
Reproductive health & 13 \\
Accidents, violence, suicide and poisoning & 4 \\
Mental health & 6 \\
Healthcare & 14 \\
Immunisation & 5 \\
Sociology & 14 \\
Anthropometry & 6 \\
Demography & 5 \\
\hline
\end{tabular}


disease", for example. These were counted in all relevant subject areas.

Most papers relate to child health (including congenital anomalies) or communicable disease. Only six were related to chronic and noncommunicable disease. The subject areas will be examined in detail below.

CHILD HEALTH

Health of Roma children has attracted particular attention. Many studies relate to communicable disease, but other issues have also been examined. From birth, there seems to be a differential in health between Roma and majority populations. In Hungary, Roma infants were twice as likely to be born prematurely and there was a significant excess of births under $2500 \mathrm{~g}$ at most gestational ages. ${ }^{12}$ This may partly reflect the association between birth weight and maternal education, with low levels of educational attainment among Roma mothers.

A Spanish study of congenital malformations ${ }^{13}$ found that recessive syndromes were seven times more common than in the reference population, a finding attributed to consanguinity ( 12 times as common as the majority population). High rates of consanguinity have been reported among Roma populations elsewhere. ${ }^{14}{ }^{15}$ The Spanish study reported relatively few cases of chromosomal and of autosomal dominant disorders, with rate ratios of 0.68 and 0.80 respectively.

There was little research on common disorders of childhood. One study from Spain ${ }^{16}$ found excess morbidity from secretory otitis media in Roma children. This was thought to be explained by socioeconomic status, not ethnic factors. Other research is eclectic. A study of childhood brain tumours in Hungary ${ }^{17}$ found a lower incidence than in the general population. Both lead poisoning ${ }^{18}$ and burns ${ }^{19}$ have been shown to be more common in Roma children, findings that are consistent with environmental exposure. ${ }^{7}$

Roma adolescents, even where drug use is prevalent, have a low rate of substance misuse ${ }^{20}$ but a 1993 case-control study ${ }^{21}$ seems to show an increase in neonatal abstinence syndrome in the offspring of young Roma mothers in Mexico between 1985 and 1991 .

\section{REPRODUCTIVE HEALTH}

Any discussion of the reproductive health of Roma people must take account of the practice of forced sterilisation of Roma women, prevalent in some countries, and its possible effect on present day help seeking behaviour.

A study of the sexual culture of Roma women in Bulgaria ${ }^{22}$ found only $61 \%$ using contraception regularly, abortions were more common than in the majority population2.41 abortions per woman, with $33 \%$ of women having had more than three-and that Roma women had their first pregnancy earlier. A more detailed study of contraceptive practices among Roma women in Spain found significantly lower levels of knowledge about barrier methods of contraception, vasectomy and tubal occlusion and periodic abstinence. The primary contraception was coitus interruptus.
KEY POINTS

- The situation of the Roma people is receiving increasing public attention as a consequence of events in central and eastern Europe.

- Published research on the health needs of this population is fragmentary.

- What research exists seems to reflect views of the Roma as threats to the majority population, either through infectious disease or their contribution to the gene pool.

- There is a need for both further research into the health of Roma people; with particular emphasis on non-communicable disease; and also for interventions that improve Roma health.

- Such research must be handled with sensitivity, recognising the social and political context of the societies concerned.

They were less likely to seek contraceptive advice than non-Roma women and had more pregnancies; leading both to more live births and terminations of pregnancy.

A Bulgarian study ${ }^{24}$ found nearly half of pregnancies where the mother was aged 13-16 to be among women of Roma origin. A study of commercial sex workers attending a sexually transmitted disease clinic in Plovdiv, Bulgaria ${ }^{25}$ found more than half to be of Roma origin.

Sero-surveys among pregnant women in Spain have indicated high rates of hepatitis $\mathrm{A}^{26}$ and hepatitis $\mathrm{B}^{27}$ in the Roma population.

\section{NON-COMMUNICABLE DISEASE}

Non-communicable disease in Roma adults has received little attention. This review yielded only three citations relating to adult disease (the remainder related to paediatric conditions). Of these only one was available. A study from Massachusetts found that, in a small sample of 58 Roma people, $73 \%$ were found to be hypertensive, $46 \%$ had diabetes, $80 \%$ hypertriglyceridaemia and $67 \%$ hypercholesterolaemia. Lifestyle factors related to ischaemic heart disease were prevalent in this sample: $86 \%$ were cigarette smokers and $84 \%$ obese. Of this small population, 39\% had occlusive vascular disease and $20 \%$ chronic renal failure. A study of cultural factors among Roma children found a high prevalence of diabetes mellitus and hypertension in family histories obtained. ${ }^{20} \mathrm{~A}$ British study found inequality in access to dental care and utilisation of preventative dental services between travellers and the general population..$^{28}$ The low birth weight among Roma populations noted earlier may be associated with subsequent adult disease. ${ }^{29}$

A few studies have examined mental health, finding an excess of suicide and parasuicide over the general population. ${ }^{30}$ In contrast, suicidal ideation is reported as less common among Roma people. 
COMMUNICABLE DISEASE

A large proportion of the literature on Roma health is devoted to communicable disease. Many papers are reports of outbreaks or cases and not the epidemiology of disease, although some draw attention to low immunisation coverage. There seems to an increased incidence and seroprevalence of many classic epidemic diseases as well as more newly identified infections.

Mycobacterial infection is reported more common among Roma than in other populations, and increasing at a faster rate. ${ }^{32}$ Leprosy was also found more prevalent among Roma than the majority population in the Spanish province of Jaen. ${ }^{33}$

Viral hepatitis has attracted much attention. Seroprevalence surveys in pregnancy ${ }^{26}$ show high levels of infection with hepatitis $\mathrm{A}$ and $\mathrm{B}$ (which can be transmitted vertically). A study in Spain ${ }^{34}$ found a seroprevalence of HAV antibodies of $82 \%$ in deprived Roma children compared with $9.3 \%$ of more affluent nonRoma children. In another Spanish study, ${ }^{35}$ three groups were compared; non-Roma children, Roma children, and children in orphanages. From seven upwards there was an excess in age specific seroprevalence of hepatitis A virus of Roma children over other groups. Overall seroprevalence was $63 \%$ among the Roma, $46 \%$ in the orphanage group and $23 \%$ among the controls. Overcrowding seemed to be a factor, as did poverty and sanitary practices. The excess in seroprevalence of hepatitis B in pregnant Roma women was also described in $1984 .{ }^{36}$ One suggested reason for the relatively high seroprevalence in Roma people may be tattooing. ${ }^{37}$ Hepatitis $\mathrm{C}$ may also be more prevalent among Roma. A seroprevalence survey of the prison population in north east $\operatorname{Spain}^{38}$ found an excess over other prisoners. There is evidence for an excess of hepatitis E morbidity among the Roma, with a study in Bohemia $^{39}$ showing a doubling in the seroprevalence of hepatitis $\mathrm{E}$ antibodies over non-Roma STD clinic attenders.

With increased rates of other blood borne virus infections and low use of barrier contraception, one might expect a high rate of HIV infection. Two studies, however, one among a prison population in Spain $^{40}$ and another limited to intravenous drug users, ${ }^{41}$ showed a significantly lower seroprevalence of HIV among Roma than non-Roma inmates.

In recent decades infection attributable to wild poliomyelitis, rather than vaccine associated viruses has been concentrated among Roma populations in some countries. ${ }^{42}{ }^{43} \mathrm{Im}$ munisation coverage tends to be low, with a study in Jordan ${ }^{45}$ reporting only a $9 \%$ immunisation rate among Roma and one in Italy reporting $26 \%$ coverage, ${ }^{46}$ although there is evidence that targeted intervention can improve rates. ${ }^{47}$ This may have implications for the eradication of the disease. ${ }^{48}$

\section{HEALTH CARE}

Several studies have found differential access to health care by Roma people. Health care is, in some instances, seen as divided: with some dis- eases generally being dealt with within the community and others requiring the services of the formal health care system. ${ }^{7}$ Relations with the formal health care sector, may in some cases be influenced by cultural factors. For some Roma a stay in hospital other than for childbirth is associated with death. ${ }^{7}$ These beliefs can lead to a rejection of some methods of health care delivery. Health care professionals may, without understanding the context, view this as irresponsible. ${ }^{49}$ More important is the influence that negative attitudes of health care workers to Roma people may have upon Roma health care. ${ }^{50}$

Ironically, in pre-industrial times Roma played an important part in the delivery of health care to much of Europe, acting as folk healers in the absence of trained physicians. As late as 1910 a German traveller in Kosovo described seeing Roma "giving quack remedies to the doctorless Albanians". ${ }^{51}$ Beliefs with regard to fate and predestiny may be a factor in the poor uptake of preventative services.

Access to care is not simply a matter of culturally insensitive provision. Fonseca quotes a Roma physician in Bulgaria as saying that his Bulgarian contacts "do the absolute minimum" in the Roma community. She describes several examples of outright discrimination. ${ }^{7}$ There may be a role for specialist link workers, ${ }^{52}$ although this is contentious.

\section{Discussion}

This review is subject to the limitations facing any literature review: incomplete ascertainment of papers and publication bias. ${ }^{53}$ The scale of the challenges is greater than for many topics. It is limited to research published in journals indexed by major bibliographic databases. These are known to provide partial coverage, which is likely to be an especial problem here, where relevant studies are likely to have been published in journals that may be difficult to obtain. Elsewhere we will be reporting on the findings from a hand search of Czech and Slovak literature on health of Roma populations, in which we found this to be so. There is a need to ensure that material that we were unable to review be accessible to a wider international audience. We also recognised that some of the published research may have been carried out for reasons other than altruism. It was nevertheless decided to report findings fully, and not to editorialise results.

The research examines health needs of a people that has been dispersed to countries as diverse as Jordan, Mexico, and the United Kingdom. Although the Roma populations in many places have adhered to traditional ways of life and share many common beliefs, the literature encompasses tremendous heterogeneity, making it difficult to generalise.

Although the literature overall is fragmentary, the most striking finding is the almost complete absence of research on noncommunicable diseases. Several possible explanations exist but each has different implications. Some may reflect the difficulties of undertaking research in marginalised populations with well developed sets of health beliefs. 
Classic risk factor epidemiology is difficult among Roma populations who, as well as being difficult to access, may regard researchers with hostility: often appropriately in view of their experiences with authorities.

There are, however, more problematic issues relating to values underlying the research. The focus on communicable disease may reflect less a concern about the health needs of the Roma but more those of the majority population. The history of public health contains many examples of actions driven by such concerns about "contagion". This concentration on communicable disease also resonates, uncomfortably, with the Social Darwinist agenda, which viewed excess communicable disease in certain populations as a means of reducing those considered to be constitutionally weak and socially undesirable. ${ }^{54}$ Such beliefs might also be seen to underlie some research on reproductive health, and may represent the same blurring of the boundary between the population perspective and eugenics that characterised Germany under National Socialism. ${ }^{8}$ In some societies, especially where strongly nationalistic sentiments have reappeared, evidence of health inequalities may be interpreted very differently than it might be in more inclusive societies. It is in the context of this climate that one must take a view on the appropriateness of different forms of intervention. Notwithstanding the evidence from the UK of the usefulness of targeted interventions, ${ }^{44}{ }^{52}$ any intervention that reinforces ideas of difference from the majority community may be divisive and cause net harm.

What limited evidence exists indicates that the health needs of the Roma population are considerable. Recognising the need for sensitivity because of the dangers arising from nationalism in some countries, there is a need to move this issue higher up the public health agenda. Such action faces a wide range of obstacles. The health needs of the Roma population lack visibility, not only because of the absence of research but also the absence of advocacy on their behalf. In many of the countries with large numbers of Roma, the public health services that, in the West, might be expected to act as agents to promote policies focusing on the health needs of minorities, do not exist. Neither do the non-governmental organisations that have been effective in the West in raising the profile of otherwise ignored issues. Similarly there is little tradition of the inter-sectoral action that would be required to mount an effective policy response.

One opportunity on the horizon is the growing interest in the Roma among international agencies and similar bodies; largely as a result of lobbying by Roma agencies. Agencies active in reform of health and social care, such as the World Bank and the Open Society Institute, have taken an increasing interest in this issue. The rights of minorities are increasingly the focus of discussions with countries hoping to accede to the European Union and are also a major issue for the Council of Europe, of which many countries in central and eastern Europe are now members.
The health of the Roma population presents a major challenge to public health professionals, especially in some countries where they are a significant minority and where there may be discrimination, social exclusion and even overt racism. There is a need to explore locally sensitive mechanisms that can begin to understand their health needs and ways of tackling them. To encourage involvement in public health research by those Roma people who have transcended discriminatory barriers to access to become health professionals may help to develop relationships with community leaders, based on trust, and pursue agendas that reflect the needs of the Roma rather than the majority population.

The authors would like to thank Helen Epstein, Jim Goldston and Ilona Koupilová for their valuable comments.

Funding: this review was performed as part of a project funded by the World Bank. However the World Bank can accept no responsibility for the views expressed.

Conflicts of interest: none.

1 The Patrin Web Journal-Timeline of Romani (Gypsy) history. http://www.geocities.com/Paris/5121/timeline.htm 1999

2 Anon. The gypsies. In: Fernández-Armesto F. Guide to the peoples of Europe. London: Times Books, 1994

3 Crowe DM. A history of the Gypsies of Eastern Europe and Russia. New York: Tauris, 1995.

4 Latham J. Roma of the former Yugoslavia. Nationalities Papers 1999;27:205-26.

5 Hancock I. The pariah syndrome: an account of Gypsy slavery and persecution. Ann Arbor: Karoma, 1987.

6 McKee M. The health of gypsies. BMF 1997;315:1172-3.

7 Fonseca I. Bury me standing: the gypsies and their journey. Fonseca I. Bury me standing: the gypsic
London: Chatto and Windus, 1995 .

8 Barondess JA. Care of the medical ethos: reflections on Social Darwinism, racial hygiene and the holocaust. Ann Social Darwinism, racial hyg
Intern Med 1998;129:891-8.

9 Braham M. The untouchables: a survey of Roma people of central and eastern Europe. Geneva: UNHCR, 1993.

10 Crowe DM. The gypsies of Romania since 1990. Nationalities Papers 1999;27:57-67.

11 Liégeois J-P, Gheorghe N. Roma/Gypsies: A European minority. London: Minority Rights Group, 1995.

12 Joubert K. Size at birth and some sociodemographic factors in gypsies in Hungary. F Biosoc Sci 1991;23:39-47.

13 Martinez-Frias ML, Bermejo E. Prevalence of congenital anomaly syndromes in Spanish gypsy population. $\mathcal{F} \mathrm{Med}$ Genet 1992;29:483-6.

14 Thomas JD, Doucette MM, Thomas DC, et al. Disease, lifestyle and consanguinity in 58 American Gypsies. Lancet 1987;ii:377-9.

15 Ferak V, Sivakova D, Sieglova Z. The Slovak gypsies (Romany) - a population with the highest coefficient of inbreeding in Europe. Bratisl Lek Listy 1987;87:168-75.

16 Suarez-Nieto C, Malluguiza-Calvo JR, Barthe-Garcia P. Climatic and racial factors related to the aetiology of secretory otitis media. ORL $\mathcal{F}$ Otorhinolaryngol Relat Spec 1984; 46:318-26.

17 Velkey I, Nagy K, Dobai J. Changes in the frequency of childhood brain tumours in north east Hungary. Orv Heitil 1995;136:2217-19.

18 Redondo MJ, Guisasola FJ. An unknown risk group of lead poisoning: the gypsy children. Eur F Pediatr 1995;154:197200.

19 Petridou E, Trichopoulos D, Mera E, et al. Risk factors for childhood burn injuries: a case control study from Greece. Burns 1998;24:123-8.

20 Mandell F. Gypsies, culture and child care. Pediatrics 1974 ; 54:603-7.

21 Perez-Bescos L, Arrate-Zugazabeitia JK, Fortea-Jimeno E, et al. The clinical and epidemiological aspects of neonatal abstinence syndrome. Bol Med Hosp Infant Mex 1993;50: 843-8.

22 Semerdjieva M, Mateva N, Dimitrov I. Sexual culture of the gypsy population. Folia Med Plovdiv 1998;40 (3B suppl 3):72-5.

23 Reig-Majoral S, Curos-Torres S, Balcells-Chiglione J, et al. Contraception: gypsy versus non-gypsy women. Aten Primaria 1999;23:63-7.

24 Porozhanova V, Boiadzhieva M. Social psychological studies of pregnant adolescents. Akush Ginekol 1995;34:9-12.

25 Tchoudomirova K, Domeika M, Mardh PA. Demographic data on prostitutes from Bulgaria - a recruitment country for international (migrant) prostitutes. Int $\mathcal{f}$ STD AIDS 1997;8:187-91.

26 Menendez MT, Cordero M, Viejo G, et al. The serum markers in the pregnant population of the basic health area of El Natahoyo (Gijon). Aten Primaria 1996;18:17-21. 
27 Delgado-Sanchez A, Bailon-Munoz E, Sanchez-Perez MR, et al. Results and analysis of research on HbsAg in pregnant women at

28 Edwards DM, Watt RG, Oral healthcare in the lives of gypsy travellers in east Hertfordshire. Br Dent f 1997;183:252-7.

29 Barker DJP. Mothers, babies and disease in later life. London: BMJ Publishing Group, 1994.

30 Zonda T, Lester D. Suicide among Hungarian gypsies. Acta Psychiatr Scand 1990; 82:381-2.

31 Palanova A, Gresikova $M$, Sekeyova $M$, et al. A minor measles epidemic in the Central Slovakia Region in 1988. Cesk Epidemiol Mikrobiol Immunol 1991;40:245-51.

32 Mihailescu P, Dediu E, Andreica S. The role of the epidemiological survey in childhood tuberculosis. Pneumoftiziologica 1995;44:29-32.

33 Delgado-Rodriguez M, Rodriguez-Contreras-Pelayo R, et al. Epidemiological aspects of leprosy in the province of
Jaen. Rev Clin Esp 1989;185:99-103.

34 Cilla G, Perez-Trallero E, Marimon JM, et al. Prevalence of hepatitis A antibody among disadvantaged gypsy children hepatitis A antibody among disadvantaged gypsy ch
in northern Spain. Epidemiol Infect 1995;115:157-61.

35 Morales JL, Huber L, Gallego S, et al. A seroepidemiologic study of hepatitis A in Spanish children. Relationship of prevalence to age and socio environmental factors. Infection 1992;20:194-6.

36 Cruz M, Dieguez A, Fos E, Hierro F. Epidemiologic survey on hepatitis B in gypsy women. Eur f Epidemiol 1988;4: 314-17.

37 Rosario-Pac M, Arnedo A, Montaner MD, et al. Epidemic outbreak of Hepatitis B from the tattoo in gypsy families. Rev Esp Salud Publica 1996;70:63-9.

38 Grupo Noroeste para el estudio de la Hepatitis C en el medio penitenciario. Seroprevalance of infection by hepatitis $C$ virus on entry to prison in the prison population in the tis $C$ virus on entry to prison in the prison population in the

39 Pazdiora P, Nemecek V, Topolcan OP. Initial results of monitoring hepatitis $\mathrm{E}$ virus antibodies in selected populamonitoring hepatitis $\mathrm{E}$ virus antibodies in selected population groups in the West Bohemia region. Prelimi

40 Martin-Sanchez V, Cayla-Buqueras JA, Gonzalez-Moris ML, et al. Evaluation of the prevalance of HIV infection in prison inmates at the time of their imprisonment during the period 1991-1995. Rev Esp Salud Publica 1997;71:269-80.
41 Martin V, Cayla JA, Moris ML, et al. Predictive factors of HIV infection in injecting drug users upon incarceration. Eur F Epidemiol 1998;14:327-31.

42 Bernal A, Garcia-Saiz A, Liacer A, et al. Poliomyelitis in Spain, 1982-84: Virologic and Epidemiologic studies. Am f Epidemiol 1987;126:69-76.

43 Strebel PM, Aubert-Combiescu A, Ion-Nedelcu N, et al. Paralytic poliomyelitis in Romania, 1984-1992. Evidence for a high risk of vaccine associated disease and reintroduction of wild virus infection. Am f Epidemiol 1994;140:111124.

44 Feder GS, Vaclavik T, Streetly A. Traveller gypsies and childhood immunization: a study in east London. $\mathrm{Br} F \mathrm{Gen}$ Pract 1993;43:281-4.

45 Reichler MR, Abbas A, Kharabsheh S, et al. Outbreak of paralytic poliomyelitis in a highly immunized population in Jordan. F Infect Dis 1997;175 (suppl 1):S62-70.

46 Aylward RB, Porta D, Fiore L, et al. Unimmunized gypsy populations and implications for the eradication of populations and implications for the eradication of 1):S86-8

47 Camara-Medina C, Perez-Garcia A, Quesada-Lupianez P, et al. Intervention with community health agents in immunization programs in the gypsy population. Aten Primaria 1994;13:415-18

48 Milanov K. Eradication of poliomyelitis in Bulgariaproblem encountered. Cent Eur F Public Health 1994;2:23-

49 Sutherland A. Gypsies and health care. West Med $\mathcal{f}$ 1992;157:276-80

50 Wetzel RC, Dean JM, Rogers MC. Gypsies and acute medical intervention. Pediatrics 1983;72:731-5.

1 Malcolm N. Kosovo: A short history. London: Macmillan, 1998.

52 Feder G, Salkind MR, Sweeney O. Traveller gypsies and general practitioners in East London: the role of the traveller health visitor. Health Trends 1989;21:93-4

$53 \mathrm{McKee}$ M, Britton A. How to review the literature on effectiveness of health care interventions. Health Policy and Planning 1997;12:262-7.

54 Haycraft JB. Darwinism and race progress. London: Sonnenschein, 1895:51-7. 